\title{
Puerto Rican Teachers' and Students' Beliefs toward Spanish Use in the English Classroom as a Way to Motivate Students
}

Creencias de profesores y estudiantes puertorriqueños sobre el uso del español en el aula de inglés como forma de motivar a los estudiantes

Crenças de professores e alunos porto-riquenhos sobre o uso do espanhol na sala de aula de inglês como forma de motivar os alunos

Vanessa Mari

https://orcid.org/0000-0003-0918-3723

Nevada State College, United States of America

vanessa.mari@nsc.edu

Kevin S. Carroll

https://orcid.org/oooo-0002-5948-8843

University of Puerto Rico Rio Piedras, United States of America

kevin.carroll@upr.edu

Received: $21 / 05 / 2020$

Accepted by peers: $26 / 08 / 2020$
Sent to peer review: $07 / 07 / 2020$

Approved: 09/09/2020

DOI: 10.5294/laclil.2020.13.2.6

To reference this article (APA) / Para citar este artículo (APA) / Para citar este artigo (APA)

Mari, V., \& Carroll, K. S. (2020). Puerto Rican teachers' and students' beliefs toward Spanish use in the English classroom as a way to motivate students. Latin American Journal of Content \& Language Integrated Learning, 13(2), 289-311. https://doi.org/10.5294/laclil.2020.13.2.6 
ABSTRACT. This paper documents English teachers' and advanced English students' perspectives on the use of Spanish in the English classroom in Puerto Rico. Using qualitative data collection methods such as interviews and focus group data, the researchers document the ways that many English teachers on the island justify their use of Spanish in the English classroom as they work to make their teaching more comprehensible. Nevertheless, the advanced students from both public and private schools who participated in this study offer a note of caution regarding the use of too much Spanish in the English classroom. Ultimately, findings suggest that many English teachers consciously or unconsciously adopt a translanguaging approach that needs to be assessed critically depending on the language proficiency and confidence of the students in their classrooms.

Keywords (Source: Unesco Thesaurus): Translanguaging; teaching English; Spanish; codeswitch; teacher perception; motivation.

RESUMEN. Este artículo documenta las perspectivas de los profesores de inglés y de los estudiantes de inglés avanzado sobre el uso del español en el aula de inglés en Puerto Rico. Mediante el uso de métodos de recopilación de datos cualitativos, tales como entrevistas y datos de grupos focales, los investigadores documentan las formas en que muchos profesores de inglés en la isla justifican su uso del español en el aula de inglés, a la vez que trabajan para hacer que su enseñanza sea más comprensible. Sin embargo, los estudiantes avanzados de escuelas públicas y privadas que participaron en este estudio observan que debe haber precaución con respecto al uso de demasiado español en el aula de inglés. En última instancia, los hallazgos sugieren que muchos profesores de inglés adoptan, consciente o inconscientemente, un enfoque de translenguaje que debe ser evaluado críticamente según el dominio del idioma y la confianza de los estudiantes en sus clases.

Palavras-chave (Fonte: tesauro da Unesco): translenguaje; enseñanza del inglés; español; alternancia de código; percepción del profesor; motivación.

RESUMO. Este artigo documenta as perspectivas dos professores de inglês e dos alunos de inglês avançado sobre o uso do espanhol na sala de aula de inglês em Porto Rico. Usando métodos de coleta de dados qualitativos, como entrevistas e dados de grupos focais, os pesquisadores documentam as maneiras pelas quais muitos professores de inglês na ilha justificam o uso do espanhol na sala de aula de inglês enquanto trabalham para tornar seu ensino mais compreensível. Porém, os alunos avançados de escolas públicas e privadas que participaram deste estudo observam que deve haver cautela quanto ao uso excessivo de espanhol na sala de aula de inglês. Finalmente, os resultados sugerem que muitos professores de inglês adotam, de forma consciente ou inconsciente, uma abordagem de translinguagem que precisa ser avaliada criticamente com base na proficiência no idioma e na confiança dos alunos em suas aulas.

Palavras-chave (Fonte: tesauro da Unesco): translinguagem; ensino de inglês; espanhol; alternância de código linguístico; percepção do professor; motivação. 


\section{Introduction}

English education on the Spanish-speaking island of Puerto Rico has been a controversial endeavor since the island nation became part of the United States in 1898 (Algren de Gutiérrez, 1987; Schmidt, 2014).

With Spanish and English holding co-official status on the island, both languages play an important role in formal education from the primary level, all the way through tertiary institutions. Despite holding two official languages, Puerto Ricans largely use Spanish among one another and throughout society. However, increased technology, as well as years of English courses in both public and private schools, have resulted in a Puerto Rican population that is more bilingual today than at any other point in its history (Pousada, 2017). Despite what seems to be an increased acceptance of bilingualism among islanders, there is much more that needs to be known about how bilingualism is fostered, particularly by English teachers, on the island.

Since 1949, the medium of instruction in Puerto Rico's public schools has been Spanish, with English being taught for one hour every school day. The transition to Spanish-medium schools in the mid-1900s coincided with a boom in public school enrollment, which prompted wealthier families, who until 1949 had taken advantage of public schools, to move their children into private schools (Torres-González, 2002). Thus, unlike the US, where approximately $9 \%$ of students study in private schools, in Puerto Rico, private school enrollment is closer to $22 \%$ (Ladd \& Rivera-Batiz, 2006). The two speaking communities represented by public (have not) and private (have) schools was the subject of Hermina (2014), who documented the different resources and experiences students of private and public schools have with regards to the English language.

With an understanding of the importance and differences between public and private English education on the island, this study seeks to better understand both teachers' and students' perspectives on how Spanish and English are used in the English classroom. Through conversations with English teachers around the island, we, as researchers and teacher educators, have noted concerns regarding how much is too much when it comes to native language support in 
the English classroom. On one hand, teachers seem to be concerned about the pedagogical practices of using Spanish in the classroom and whether such practices were backed by educational research. On the other hand, they describe real anxieties about not meeting the needs of their students, as well as being seen as inadequate by their students and colleagues for using students' dominant language in their formal teaching. Despite the limitation that this current study includes only teachers and advanced English students from public and private schools in western Puerto Rico, we are hopeful that the research will prompt additional studies, looking at the ways in which English can be taught effectively.

\section{How English Instruction Has Evolved in Puerto Rico}

Historically, the language of instruction in public schools has been the battleground of colonization, and there have been a variety of different language policies that have impacted the medium of instruction. According to Schmidt (2014), since the invasion of the island by the United States, language education on the island has experienced three different periods: the Americanization era (1898-1948), the Puertoricanization era (1949-1968), and the Bilingualization era (1969-present). Over time, English instruction in schools has changed from mostly or entirely English medium (during the Americanization period) to one hour of English instruction every school day during the Puertoricanization era. The Bilingualization era has seen continued Spanish-medium education in the island's public schools, but the era is characterized by increased bilingual private schools and more willingness on the part of islanders to use both Spanish and English. According to Puerto Rico's Department of Education, teachers are expected to promote bilingualism for "students' intellectual enrichment and growth" (Puerto Rico Department of Education, 2016, p. 32). While Spanish and English bilingualism is on the rise in Puerto Rico, the majority of islanders use Spanish throughout their daily lives (Pousada, 2017).

Today, most public schools in Puerto Rico teach all courses in Spanish with the exception of a daily English course. With very few exceptions, public schools on the island do not offer other language courses as part of their curriculum. The majority of bilingual schools are, thus, 
offered in the private sector, where parents assume their children will receive a better education than in traditional public schools (PérezCasas, 2016; Ladd \& Rivera-Batiz, 2006).

Despite daily exposure to English in schools, a large number of Puerto Ricans do not consider themselves to be fluent English speakers. According to census data, only $19 \%$ of the population self-identifies as speaking English "very well" (US Census Bureau, 2020). Despite the limitations of self-reported data on the census, these responses provide us with an overarching view that the majority of Puerto Ricans do not feel confident speaking English. Although islanders believe that their English proficiency is not as adequate as they would hope, Puerto Ricans are exposed to English in ways that residents of other Spanish-speaking countries are not. For example, a daily English course throughout primary and secondary education is not the norm in Spanish-speaking countries around the world. Furthermore, the colonial relationship with the US has made English ubiquitous in a number of different domains of language use, such as the internet, signage, and textbooks at the university level. Such language use on the island, as well as in formal education contexts, speaks to the fluidity of language on the island.

\section{Review of the Literature}

The linguistic fluidity described above is best explained by translanguaging, a relatively new term that has gained in popularity, particularly among US and European researchers. These researchers have worked to document how language is used in formal learning environments, as well as society at large. The focus of those who have adopted a translanguaging lens is not on defining language boundaries and the domains in which one language is spoken over another. For these researchers, the locus of attention should be on how students, teachers, and people within society "language" (Garcia \& Wei, 2014).

The term translanguaging was first coined in Welsh by Cen Williams in the 1990s to describe a pedagogical approach that allows students to read content in one language and discuss it in another (Beres, 2015). As the first person to use the term translanguaging, Williams was the first to document the deliberate use of reading in one language and 
discussing the content of that reading in another language. Those original ideas of using translanguaging for purely pedagogical means have been expanded in recent years by Ofelia García, who argues for most post-structuralist approaches to linguistics where the very notion of languages constructs is called into question (García \& Wei, 2014; Otheguy et al., 2019). For instance, Garcia and Wei (2014) describe translanguaging as "extend[ing] our traditional definitions of language and bilingualism. It refers to the ways in which bilinguals use their complex semiotic repertoire to act, to know, and to be" (p. 137). When teachers work to incorporate and build on their students' linguistic and cultural repertoires, the results can be transformational in that minority students whose language and culture has long been absent in school curricula are now able to relate on linguistic and cultural levels (Mazak, 2017; Palmer et al., 2014; Wei, 2011; Zuniga et al., 2018). Such use of language in formal educational contexts can work to have an empowering impact on both teachers and students because they can work together to complement and improve their use of multiple languages.

Despite great popularity of the term translanguaging, over the past decade there have still been varying points of view from which translanguaging can be understood, particularly because researchers around the world have adapted the term to meet the linguistic and cultural idiosyncrasies of their particular contexts. While definitions abound (for slightly different takes on the term, see Beres, 2015; García \& Baetens Beardsmore, 2009; García \& Lin, 2016; García \& Wei, 2014; Mazak, 2017), one constant question remains: In language courses, how much is too much when it comes to using students' dominant language(s)? That is to say, while there is less controversy about the use of students' multiple linguistic repertoires in mathematics, science, or other content-area courses, personnel tasked with teaching languages have often stuck to one language in classroom policies (Cummins, 1992, 2008). Even when language teachers find themselves using a language other than the official medium of the course, there is often a feeling of resentment, insecurity, or even self-loathing for not meeting (sometimes imagined) societal or institutional expectations (Zuniga et al., 2018).

Though few studies evaluate the idea of translanguaging and motivation, some researchers have used Norton's (2013) notion of 
investment to make a connection with translanguaging. The notion of investment acknowledges how L2 learners' complex social identities and political contexts can affect a student's investment in learning in an L2 course. For example, Palmer et al. (2014) observed teachers and found that when they allowed, valued, and mirrored students' ways of speaking and their linguistic choices, it changed the dynamic of the classroom. As they explained, "translanguaging pedagogies appeared to open up spaces for students to engage in sensitive and important topics (e.g., immigration, identity) and take risks to express themselves in developing languages (e.g., attempting to translate)" (p. 769). Thus, this research teaches us that, when teachers incorporate multiple facets of their students' linguistic repertoires in the classroom, they can create a positive classroom environment where students are engaged and motivated. As such, we recommend that future researchers interested in translanguaging examine how translanguaging impacts students' motivation and investment in the classroom.

One of the issues in the first wave of translanguaging research has been that the majority of contexts that have documented its use have been content-area classrooms or bilingual education programs, with particular interest in how language plays out at the elementary school level (Poza, 2018; Sayer, 2013). More recently, researchers have documented translanguaging and biliteracy practices in higher education (Palfreyman \& van der Walt, 2017), yet with the exception of Carroll's (2016) article about the use of translanguaging and literature circles in a basic English course at the university level in Puerto Rico, little is known about high school students and their perceptions of translanguaging in English courses, particularly within the context of Puerto Rico.

Since the beginning of the field of teaching English to speakers of other languages (TESOL), researchers, professors, teachers, and students have grappled with the issue of using students' more dominant language in the English classroom (May, 2013). While the multilingual turn in TESOL has opened many researchers to better understand the benefits of bringing in students' linguistic repertoires to the English classroom (May, 2013), Puerto Rican teacher preparation programs, as well as hiring tendencies of the Puerto Rico Department of Education, privilege teachers who present themselves as able to teach entirely 
in English. As such, the strict division of English and Spanish in English courses on the island is the idealized norm (Carroll \& Sambolín, 2016). Furthermore, a recent study published by Eisenstein Ebsworth, et al. (2018) highlights Puerto Rican English teachers' insights regarding a host of different education and language-acquisition-related topics. Their findings echo the experiences that English teachers on the island struggle with low remuneration and lack of adequate resources, and some report having English-teaching colleagues whose language proficiency in English is weak. Thus, for the remainder of this paper, we will lay out the research methods employed to better understand how teachers in both public and private schools report using language in their English classrooms. Furthermore, we look to bring into the conversation the voices of students who have their own expectations on what an English class should look like.

\section{Method}

The research presented herein was part of a larger, mixed methods study $^{1}$ (Creswell, 2014) that used both quantitative and qualitative data to examine motivation and its role in the acquisition of English from the perspective of teachers and students (see Mari, [2017] for details on the larger study). For this particular publication, we use the qualitative sub-set of the larger study, which implemented an interview protocol used in other studies with second language learners to understand their thoughts, feelings and anxieties about learning a second language (Dörnyei \& Hadfield, 2014). Such data collection methods are described in detail in how to conduct individual interviews as well as focus groups by Creswell (2014). Ultimately, two participant groups were created: teachers and students. The teacher participants were interviewed individually, whereas the students participated in two focus groups. For this study, we focus on two salient themes that emerged from an adapted interview protocol originally developed by Dörnyei and Hadfield (2014) that impact students' motivation: the use of Spanish in the English classroom and students' anxieties related to the use of English.

1 Mari, V. (2017). "Motivation to Learn and Teach English in Puerto Rico's Public and Private Schools." University of Texas, San Antonio. 
There was a total of ten participants in the teacher group, who worked at seven different schools (four private and three public). These interviews were conducted primarily in Spanish, with three of the teachers preferring to conduct most of the interview in English. The interviews were recorded and transcribed verbatim. Of the ten teacher participants, there was an even divide between public and private teacher participants. Similar to the distribution of bilingual curriculum in Puerto Rican public and private schools where few schools offer an immersion curriculum, only three of the ten teachers hailed from schools that offered an English immersion. The interview questions for the teachers were developed by the first author, in consultation with a group of experts familiar with issues related to English education in Puerto Rico. These questions looked to better understand how teachers described their students' motivation to learn English.

In addition to the interviews with the teachers, this paper includes fourteen twelfth-grade high school student participants. These students participated in two different focus groups based on their school membership (private or public school). Using a convenience sampling method in order to attract the largest number of participants, the first author interviewed two groups of students who were both characterized as being in the advanced section of English at their respective schools. While we acknowledge that this is an obvious limitation to this study, so little is known about students' perspectives on English education in Puerto Rico that we felt it prudent to document their unique takes on English.

The students were evenly distributed between private and public-school students. The interview was conducted by the first author and was done mostly in Spanish with some instances where the students chose to speak in English. The interviews were audio-recorded and transcribed. The average focus group lasted an hour and a half. Both groups received the same amount of English instruction: one hour a day, five days a week in an advanced English classroom. The rationale behind selecting students in twelfth grade stemmed from wanting to interview students who had been in the Puerto Rican school system the longest and could offer insight into their entire English schooling experience.

The interviewer employed a structured interview protocol for the teachers and students. The questions administered to the students 
were adapted from Dörnyei and Hadfield (2014), who provide a list of questions for teachers to ask students in order to understand what motivates them to learn a language and use this information to inform their teaching practices. These questions were framed using Dörnyei's (2005) L2 motivation self-system framework, which explores the ideal self, the ought-to self, and the students' L2 learning experiences. Dörnyei (2009) defines ideal self as the L2 learners' motivation to close the gap between their actual and ideal selves. The ought-to self explores the L2 learners' beliefs about the attributes they ought to possess to meet learning expectations. The L2 learning experience is concerned with the learning environment and experiences that the student experiences in the classroom, such as the use of Spanish when learning English. When we take all of these three ideas of motivation and the role it has with the self (ideal, ought and the L2 learning experience) we can further explore the connections that teachers and students make with Spanish use in the classroom. All of these encompass what Dörnyei frames as L2 learning motivation.

\section{Findings}

With the larger study focusing on teacher and student motivation and how it impacts their teaching and learning respectively, the two most salient themes that emerged had to do with how using Spanish in the English classroom could negatively impact students' motivation to learn English. The second theme that emerged across the data sets had to do with language anxiety and how both teachers and students expressed their fears and anxieties related to using English.

\section{Esto es una clase de inglés... No de español}

"This Is an English Class... Not a Spanish One" (Focus group, Public school student, August 20,2016) reads the quote above, which was emblematic of some of the voices of student participants and their frustration with having a large amount of Spanish being used in the English classroom. Despite the co-official status of Spanish and English at the nation-state level, schools and teachers have been provided the space to create and re-create their local-level language policies (Carroll, 2016). All of our participants agreed that it is common for a great deal 
of Spanish to be used in the English class. This Spanish may come from a teacher who predominantly uses Spanish to teach the English class, or it may come in the form of discussions between students as they try to make sense of a course assignment or reading that was required in English. According to our teacher participants, they all reported making conscious decisions on the targeted nature of when they were going to use Spanish in their English classroom. However, our advanced English student participants described their twelve years of English learning experiences as being largely laced with Spanish at just about every turn, as was described in the quote that started this section.

Public School Teacher 2 mentioned in her interview that she herself uses English exclusively in her classroom and was surprised when one of her eleventh-grade sections was excited to take class with her because they said that for them it was the first time they would take an English class that was completely in English. Such experiences highlight the fact that some, but definitely not all, English teachers on the island teach their courses predominantly in Spanish. This concern was echoed throughout both of the student focus groups. Public School Student 5 made this point clear when he said, "Me molesta cuando la clase de inglés es enseñada en español. Casi siempre la maestra habla en español y eso es frustrante para nosotros que queremos aprender" ("It bothers me when English class is taught in Spanish. Most of the time the teacher talks in Spanish and that is frustrating for those of us that want to learn."). All the students in the focus group agreed by either nodding or verbally expressing their support. Throughout the focus groups with the student participants, it was made clear that they overwhelmingly felt it was not appropriate for teachers to use Spanish in their English class. They repeatedly stated that they wanted an English class that was taught exclusively in English. For example, one student from public school complained that the teachers "honestly talk more in Spanish than in English" (Public School Student 5). While the students did not elaborate on under what circumstances some Spanish would be acceptable, they did uniformly believe that English class should be taught in English.

As the interviews show, teachers and students attested to the fact that some English teachers in Puerto Rico use a great deal of Spanish in their English classroom. While the teacher participants denied using 
such teaching practices themselves, they all attested to knowing colleagues or friends who taught their classes largely in Spanish. When asked if they themselves used Spanish, all of the participants noted that they did so sparingly, and when they chose to do so, it was done in a targeted manner. Such was exemplified by Public School Teacher 3 when she said, "Sometimes the students look at you with blank stares. I have to use Spanish so that they can complete the work."

Despite the teachers' acknowledgment of their use of Spanish in targeted ways, students demonstrated apprehension toward the use of Spanish in the classroom. Below is an exchange between Public School Students 1, 3, and 5 in their focus group.

\section{Excerpt 1.}

S1. Yo estudié en escuela privada toda mi vida y el inglés es muy diferente. El que se da en la escuela privada es muy diferente al que se da en la [esta] escuela pública.

I studied in private school all my life and English was very different. The one [English] they teach in private school is very different to the one in [this] public school.

S5. Sí, eso es cierto.

Yes, that is correct.

S3. Cuando yo entré a décimo, a mí me empezaron a dar cosas que yo aprendí en quinto grado.

When I entered tenth grade, they started teaching me things I had learned in fifth grade.

S5. Es verdad.

Yes, it's true.

S3 Yo también estuve en la escuela privada y tuve esa misma experiencia cuando vine a la escuela pública.

I was also in private school and had that same experience when I came to public school.

S5. Yo también viví un año allá afuera en California y era bien diferente. Enseñaban en inglés como se supone que sea.

I also lived for a year in California and it was very different there. They taught in English like it is supposed to be. (Public school student 1, 3, 5, August 23, 2016). 
Their apprehension regarding the use of Spanish in the English classroom seems to stem from years of negative experiences with teachers who predominantly used Spanish or allowed students to exclusively use Spanish. Furthermore, the conversation above between Students 1, 3, and 5 demonstrates what most participants believed, which was that private schools were more rigorous when it came to English education. Student 5's comment at the end is also noteworthy in that her experience in California gave her perspective on how English is "supposed to be" taught. A follow-up question confirmed that, while she was in California, the teachers did not use Spanish at all. Thus, while it seems to be a positive thing that teachers feel that they can use Spanish to help students who need native language support, according to our student participants, such language use is often abused or used so liberally that they do not challenge those with more advanced proficiency.

\section{Language anxiety}

As described in the previous section, student participants' discontent with excessive use of Spanish in the English classroom, was countered by our teacher participants' concerns with their students' language anxiety. A teacher from private school said in her interview: "Les da mucho miedo hablar en inglés." (They are afraid to speak in English). Because of this perceived language anxiety, our teacher participants harped on the importance for them to create and provide a comfortable learning environment in order to help students overcome their fear of speaking English. The word "fear" was used often in the interviews, as the teachers described how many of the students were afraid of speaking in English. It is observed in the student data that they acknowledged this fear but distanced themselves from it by assigning the fear of speaking English to a peer who was not present in the focus group. Some of the examples of this fear were noted above when discussing the reasons participants described for wanting to learn English.

The most common words used by the student participants to describe their peers' fear of speaking English were miedo (fear), vergüen$z a$, (shame), and cohibido/a (self-conscious). Regardless of the students' self-reported proficiency in English, all the students expressed these concerns, and the teachers reinforced that students generally have them. 
To help students overcome their apprehension, the teachers said they strived to create a comfortable learning environment. One way that they tried to do this was by permitting the use of Spanish in the English class as a way of merging both literacies. For example, Public School Teacher 7 reported accepting work written in Spanish:

They turn in the Spanish version but also turn in the semi-translated version into English. But that's something I have to ask them constantly, to produce in English. And I know it is because they compare themselves to the teacher and are worried about accents.

To justify such a practice, Public School Teacher 7 explained that her priority was for students to produce, regardless of their language proficiency. She also suggested that some students are hesitant to produce work in English because of their accent; she believed that students thought they should model the language proficiency of the teacher. Tarnopolsky (2008) argues that a nonnative speaker of the language being taught has the advantage of "using the students' mother tongue to facilitate and accelerate the learning process" (p. 5). The teacher who is a native speaker of Spanish recognizes that having such language flexibility in her written assignments will help students develop their writing in both languages.

Another private school teacher shared her strategies for addressing students' anxiety about how they speak English:

Sometimes I show them videos of people who have accents because I want them to know that having a thick accent doesn't mean you don't know the language. So, by showing them these videos, they can see that it is not only them that have an accent. It is important for them to understand that everybody has an accent. (Private School Teacher 2)

Private School Teacher 2 acknowledges students' fear of communicating in English and approaches it by showing them videos of diverse language varieties in the US. Furthermore, to demonstrate another way she helped lower students' anxiety, this teacher described how students use Spanish in her classroom when they write essays and at times when they have questions and do not feel comfortable asking in English. Similar to Private School Teacher 2, all of the teachers interviewed reported using Spanish as a resource. This was exemplified by 
Public School Teacher 5's explanation of how she allowed students to use what she referred to as "Spanglish," or a mixture of Spanish and English, to complete a written task: "I always encourage them to work. If you don't know English, then just do it in Spanglish; they will learn eventually, and they do. So, I just tell them to write about what's in their heads and they like that."

Thus, Public School Teacher 5 was affording students the opportunity to use a linguistic repertoire that includes both Spanish and English in order to complete a task. She reported that, in her experience, giving them the opportunity to do so helps their progress in English because it takes away the pressure of having to use one language "perfectly." Teachers from both private and public schools expressed similar ways of using the students' first language to build upon their second.

Another participant, Public School Teacher 3, shared how she incorporated Spanish into her lesson: "Ellos le tienen terror al escribir. Yo les digo que escriban en Spanish, solamente escriban." (They are terrified of writing. I tell them to write in Spanish, just write.)

Again, for Public School Teacher 3, the approach to combat student anxiety toward English was to allow them to use Spanish to at least get them to participate actively in the class and start to think about the given task.

Another way in which teachers reported helping students with their anxiety was by explaining certain terms in Spanish for their lessons. According to Public School Teacher 3, this was particularly the case when teachers were covering challenging texts like Shakespeare. Public School Teacher 7 added that she had to use Spanish because she knew some of the students had very basic proficiency in English and could not understand her when she spoke exclusively in English. While student participants admitted experiencing anxiety in their use of English, teachers identified student anxiety as one of the most important factors impacting the success of their students.

\section{Discussion}

Through interviews with English teachers and focus groups with students, the debate about why, how, and when Spanish should be used in the classroom becomes clearer. The advanced English students who 
participated in this study had very clear expectations about their English classes in that they felt that Spanish should play little to no role in them. However, while the English teacher participants could attest to the fact that many teachers use Spanish in the English classroom, their own particular use was seen as being done to benefit students, particularly in order to lower their anxiety.

Thus, within the context of Puerto Rico, English teachers are consistently forced to decide whether they should use Spanish to facilitate the learning of English. While the use of multiple languages in content classrooms has shown many benefits in the process of learning content and language (Gort \& Sembiante, 2015; Hornberger \& Link, 2012; Sayer, 2013; Zuniga et al. 2018), such practices are often highlighted in bilingual education settings where elementary school teachers have more than just fifty minutes a day with students. Unfortunately, while studies documenting translanguaging in content courses or bilingual education programs abound, far less attention has been paid to what translanguaging looks like in classrooms where the content is a language itself (Menken \& Sánchez, 2019). This is particularly the case in the context of Puerto Rico, where the focus of the only published study looking at translanguaging in an English classroom was at the tertiary level, where students select their own courses and generally have passed a standardized test for admission (Carroll \& Sambolín, 2016). As they argued and we argue here, using translanguaging in English classrooms in Puerto Rico is not inherently negative; however, the overuse of Spanish in the English classroom can have a negative impact on students' motivation.

Our student participants had very particular expectations when it came to how English should be taught, as they reported very clear separationist language ideologies (Cummins, 1992, 2008). While we acknowledge that our participants were students in advanced English classrooms and thus excelled in the subject area more than the majority of their peers, they were unanimous in the disapproval of so much Spanish being used in the English classroom. The teacher participants, however, highlight that these advanced students who participated in the focus group were representative of a small cross-section of English students in Puerto Rico and that the vast majority of traditional English students really need first-language support in the English 
classroom. As such, the teacher participants attest to the fact that they often need to use Spanish in order to make their teaching more comprehensible to their less proficient students.

Given that teachers generally have a great deal of flexibility to use Spanish in targeted ways in the English classroom and that doing so can potentially help in decreasing the anxiety that so many students mentioned in their focus groups, we recommend that English teachers self-reflect about their own use of Spanish and English, as well as the linguistic needs and resources of their students. For many students enrolled in K-12 schools in Puerto Rico, the English teacher can be the only source of comprehensible input in English; thus, teachers are advised to heed our student participants' suggestions to teach as much as possible in English. With that said, there are a number of other ways in which the English teacher can build on their students' linguistic repertoires to reduce anxiety and increase purpose in their English classroom. Below, we outline two potential areas for English teachers in Puerto Rico to incorporate translanguaging in the ESL classroom in a targeted and more effective manner, which could result in more English being used in the classroom but, at the same time, lowering students' anxiety.

\section{Using Bilingual and Culturally Relevant Texts}

Getting students interested in reading in their second or even their first language can be a challenging task for any teacher, particularly when textbooks provided by schools and districts often include literature that is difficult for minority students to connect with (Young \& Hadaway, 2006). Within the context of Puerto Rico, while Puerto Rican students are the majority, they were not the target audience of the texts used in English classrooms, as they are largely published by non-Puerto Ricans or authors who do not write about topics that relate to life on the island. Thus, teachers who want to create a love of reading need to select texts that their students can engage with and where they have the background knowledge to make connections. Therefore, bringing in texts written by Puerto Rican authors in English where Spanish is often sprinkled into the texts can potentially make reading inside and outside the classroom a more meaningful event. Another option for English teachers who are tied to a specific text published 
in the assigned textbook is to have students re-create bilingual texts or rewrite or translate portions of the text from English into different varieties of Spanish. Using such translation activities brings back Cen Williams's original pedagogical approach to translanguaging, where, through the process of translation, students must internalize and comprehend what they are reading before they are able to write in their first language (Beres, 2015).

Another possibility related to using bilingual or culturally relevant texts is organizing students into literature circles. In literature circles, students are divided into groups where each student is given a particular role. The group works together to make connections to the required text, and often the group co-constructs something in writing or presents their findings to the class. Carroll (2016) documents this strategy in a university-level basic English course, which could easily be adapted to a primary or secondary educational context.

\section{Writing activities}

Incorporating writing activities that have an authentic purpose is important for second-language learners and also makes them more meaningful. Thus, in a high school English class such as the one that the student participants were enrolled in, having them write college admission essays makes a lot of sense. After the teacher has modeled what is expected, prewriting and even portions of the drafting process might occur in Spanish and English, with the final product being completed totally in English. This allows students to potentially work with their classmates in brainstorming and identifying the best approach to writing the college admission essay, but it also provides an authentic and real-life exercise that can potentially motivate the student.

Another thing that needs to be taken into consideration when implementing translanguaging into the writing curriculum is knowing who is enrolled in your class, what their needs are, and what characterizes their linguistic repertoires. The Espinosa et al. (2016) handbook on translanguaging pedagogy for writing is an excellent resource for teachers hoping to systematically build on their students' linguistic resources while, at the same time, decreasing some of the anxiety associated with learning a second language. 


\section{Additional considerations}

Throughout the interviews with the teachers, they expressed knowledge of the benefits of having flexible bilingual practices in their classroom. However, given that so many of the student participants reported taking courses taught in Spanish, English teachers seem to need increased training on how they can rethink their classroom to be one where students feel challenged but, at the same time, supported. Thus, an important next step is to provide in-service professional development to teachers, as well as revisit preservice teaching preparation programs, where it is often taught that Spanish has no place in the English classroom. Instead, we need to use resources like García et al. (2017) to equip English teachers with the tools they need to understand their role as one of the primary providers of oral English to their students and work with them to innovate and create assignments and classroom experiences that bring in linguistic realities, both Spanish and English, into the classroom.

Normalizing translanguaging in formal educational environments and preparing English teachers to challenge English-only language policies in schools, particularly when the lived reality of students outside of school is not monolingual, is a great start. By challenging and pushing back on the separation of language in the English classroom, students and teachers alike can work to push back on the myth that an "English only" classroom is the best pedagogical practice and way to learn a language.

When discussing translanguaging, teachers talked about its pedagogical implementation in the classroom, while students focused on what they perceived as negative experiences with Spanish use in the classroom. According to the students, Spanish is used consistently during instruction but should be used less often, if at all. Teachers, however, encouraged their students to also use Spanish in their writing if they did not know how to write a word or phrase in English. However, students who are already proficient in the language might not need to rely on these practices in order to make meaning of the task. Thus, for advanced students of English, teachers' use of Spanish in the classroom can be demotivating and frustrating. 


\section{Concluding Remarks}

Throughout this study, we sought to document the voices of public and private school students and teachers of English hailing from the western region of Puerto Rico. Using individual interviews with teachers and focus groups with advanced English students, our participants voiced real concerns about the use of Spanish in the English classroom as well as the importance of motivation in the learning of a second language. Our participants also described how the schools represented by the participants had relatively flexible language policies that permitted teachers to bring Spanish into their English classrooms. Unfortunately, from the educational experiences of our student participants, this was done too often. Despite our support of translanguaging and the doors that it can open in terms of motivating students, we recognize that, in order to successfully learn any second language, one needs to be challenged. As such, teachers can challenge their students in many different ways, which does not necessarily preclude the use of targeted Spanish in the English classroom in Puerto Rico, but which does require teachers to rethink and potentially retrain on how they can use English and students' multiple linguistic repertoires more strategically.

\section{References}

Algren de Gutiérrez, E. (1987). The movement against teaching English in the schools of Puerto Rico. University Press of America, Incorporated.

Beres, A. M. (2015). An overview of translanguaging: 20 years of "giving voice to those who do not speak." Translation and Translanguaging in Multilingual Contexts 1(1),103-118. http://doi.org/10.1075/ttmc.1.1.05ber

Carroll, K. S. (2016). Language policies in Puerto Rican higher education: Conflicting assumptions of bilingualism. Current Issues in Language Planning, 17(3-4), 260-277. https://doi.org/10.1080/14664208.2016.1201186

Carroll, K. S., \& Sambolín, A. N. (2016). Using university students' L1 as a resource: Translanguaging in a Puerto Rican ESL classroom. Bilingual Research Journal, 39(3-4), 248-262. https://doi.org/10.1080/15235882.2 016.1240114

Creswell, J. (2014). Research design: Qualitative, quantitative, and mixed methods Approaches (Vol. 4). SAGE. 
Cummins, J. (1992). Bilingual education and English immersion: The Ramírez Report in theoretical perspective. Bilingual Research Journal, 16(1-2), 91-104. https://doi.org/10.1080/15235882.1992.10162630

Cummins, J. (2008). Teaching for transfer: Challenging the two solitudes assumption in bilingual education. In Encyclopedia of Language and Education (Vol. 5) (pp. 66-75). Springer https://doi.org/10.1007/978-0387-30424-3_116

Dörnyei, Z. (2005). The psychology of the language learner: Individual differences in second language acquisition. Lawrence Erlbaum Associates.

Dörnyei, Z. (2009). The L2 motivation self system. In Z. Dörnyei \& E. Ushiosa (Eds). Motivation, Language Identity \& the L2 Self (pp. 9-42). Multilingual Matters.

Dörnyei, Z, \& Hadfield, J. (2014). Motivating learning. Taylor and Francis.

Eisenstein Ebsworth, M., Ebsworth, T. J., \& Cai, C. (2018). English acquisition in Puerto Rico: Teachers' insights. Bilingual Research Journal, 41(1), 69-88. https://doi.org/10.1080/15235882.2017.1413441

Espinosa, C., Ascenzi-Moreno, L., \& Vogel, S. (2016). A translanguaging pedagogy for writing: CUNY-NYSIE guide for educators. https://www. cuny-nysieb.org/wp-content/uploads/2016/05/TLG-Pedagogy-Writing-04-15-16.pdf

García, O., Johnson, S. I., \& Seltzer, K. (2017). The translanguaging classroom: Leveraging student bilingualism for learning. Caslon Publishing.

Garcia, O., \& L. Wei. (2014). Translanguaging: Language, bilingualism and education. Palgrave Macmillan UK.

García, O., \& Baetens Beardsmore, H. (2009). Bilingual education in the 21st Century: A global perspective. Wiley-Blackwell Pub.

García, O., \& Lin, A. (2016). Extending understandings of bilingual and multilingual education. In O. Garcia, A. Lin, \& S. May (Eds), Bilingual and multilingual education (pp. 1-20). Springer International Publishing.

Gort, M., \& Sembiante, S. F. (2015). Navigating hybridized language learning spaces through translanguaging pedagogy: Dual language preschool teachers' languaging practices in support of emergent bilingual children's performance of academic discourse. International Multilingual Research Journal, 9(1), 7-25. https://doi.org/10.1080/1931 3152.2014.981775

Hermina, J. (2014). Two different speech communities in Puerto Rico: A qualitative study about social class and children learning English in public and 
private schools of the island (Unpublished Dissertation). University of New Mexico, Albuquerque.

Hornberger, N. H., \&, Link, H. (2012). Translanguaging in today's classrooms: A biliteracy lens. Theory Into Practice, 51(4), 239-247. https:// doi.org/10.1080/00405841.2012.726051

Ladd, H. F., \& Rivera-Batiz, F. L.. (2006). Education and economic development. In S. M. Collins, B. Bosworth, \& M. A. Soto-Class (Eds.), The Economy of Puerto Rico: Restoring Growth (pp. 198-238). Brookings Institution Press.

Mari, V. (2017). Motivation to learn and teach English in Puerto Rico's public and private schools. University of Texas San Antonio.

May, S. (2013). The multilingual turn: Implications for SLA, TESOL, and bilingual education. Routledge.

Mazak, C. M. (2017). Introduction: Theorizing translanguaging practices in higher education. In C. M. Mazak \& K. S. Carroll (Eds.), Translanguaging in higher education: Beyond monolingual Ideologies (pp. 1-10). Multilingual Matters.

Menken, K., \& Sánchez, M. T. (2019). Translanguaging in English-Only schools: From pedagogy to stance in the disruption of monolingual policies and practices. TESOL Quarterly, 53(3), 741-767. https://doi. org/10.1002/tesq.513

Norton, B. (2013). Identity and language learning: Extending the conversation $\left(2^{\text {nd }}\right.$ Ed). Multilingual Matters.

Otheguy, R., García, O., \& Reid, W. (2019). A translanguaging view of the linguistic system of bilinguals. Applied Linguistics Review, 10(4), 625651. https://doi.org/10.1515/applirev-2018-0020

Palfreyman, D. M., \& van der Walt, C. (2017). Academic biliteracies: Multilingual repertoires in higher education. Multilingual Matters.

Palmer, D. K., Martínez, R. A., Mateus, S. G., \& Henderson, K. (2014). Reframing the debate on language separation: Toward a vision for translanguaging pedagogies in the dual language classroom. The Modern Language Journal, 98(3), 757-772. https://doi.org/10.1111/ modl.12121

Pérez-Casas, M. (2016). Codeswitching and identity among Island Puerto Rican bilinguals. In R. Guzzardo Tamargo, C. Mazak, \& M. C. Parafita Cuoto (Eds.), Spanish-English codeswitching in the Caribbean and the US (pp. 37-60). John Benjamins Publishing. 
Pousada, A. (2017). Being bilingual in Borinquen: Student voices from the University of Puerto Rico. Cambridge Scholars Publishing.

Poza, L. E. (2018). The language of ciencia: Translanguaging and learning in a bilingual science classroom. International Journal of Bilingual Education and Bilingualism, 21(1),1-19. https://doi.org/10.1080/13670050.20 15.1125849

Puerto Rico Department of Education. (2016). English program: Revised curriculum framework. https://www.uprm.edu/ppm/wp-content/uploads/sites/47/2017/08/Curriculum_Framework_ENGLISH.pdf

Sayer, P. (2013). Translanguaging, TexMex, and bilingual pedagogy: Emergent bilinguals learning through the vernacular. TESOL Quarterly, 47(1), 63-88. https://doi.org/10.1002/tesq.53

Schmidt, J. (2014). The politics of English in Puerto Rico's public schools. Lynner Rienner.

Spradley, J. P. (2016). The ethnographic interview. Waveland Press

Tarnopolsky, O. (2008). What do you teach EFL for? Just for kicks? IATEFL Voices, 205(5).

Torres-González, R. (2002). Idioma, bilingüismo y nacionalidad: la presencia del inglés en Puerto Rico. La Editorial, University of Puerto Rico.

US Census Bureau. (2020). Census Data. https://data.census.gov/cedsci/all? q=puerto\%20rico\%202013-2017\&g=0400000US72 \& hidePreview $=$ false $\&$ tid $=$ ACSDP1Y2017.DP05 \&y=2017\%3A2013\&vintage=2017\&layer=VT_2017_040_00_PY_D1\&cid=DP05_0001E)

Wei, Li. (2011). Moment analysis and translanguaging space: discursive construction of identities by multilingual Chinese youth in Britain. Journal of Pragmatics, 43(5),1222-1235. https://doi.org/10.1016/j.pragma.2010.07.035

Young, T A., \& Hadaway, N. L. (2006). Supporting the literacy development of English learners: Increasing success in all classrooms. International Reading Association.

Zuniga, C. E., Henderson, K. I., \&. Palmer, D. K. (2018). Language policy toward equity: How bilingual teachers use policy mandates to their own ends. Language and Education, 32(1),60-76. https://doi.org/10.108 0/09500782.2017.1349792 